The Journal of Vitaminology 6, 158-162 (1960)

\title{
COLORIMETRIC ESTIMATION OF VITAMIN A AND $\beta$-CAROTENE WITH ANTIMONY PENTACHLORIDE
}

\author{
TOSHIRO MURATA AND JUNKO NAGASHIMA \\ Pharmaceutical Faculty, Kumamoto University, Kuhonji, Oemachi, \\ Tsuboi, Kumamoto
}

(Received February 19, 1960)

The most prevalent chemical method for estimating vitamin A is based on the Carr-Price reaction, involving the sensitive coloration of both vitamin $A$ and $\beta$-carotene with antimony tricholoride. The mechanism of the color formation was studied by Meunier (1), and it was assumed to be due to the replacement of the lone pair of the electron belonging to the OH-group in the structure of vitamin A. At first the oxonium compound was formed, followed by the transformation of the double bonds in the structures, mesomerism, wherby a color was formed due to halochromy.

In practice, vitamin $\mathrm{A}$ is dissolved in chloroform, to which chloroform solution of antimony trichloride is added. A great amount of antimony trichloride, however, is required for developing the color sufficiently. In order to obtain the suitable color density for estimation, $10^{4}-10^{5}$ times moles of antimony trichloride must be added to one mole of vitamin $A$. It is also the case with $\beta$-carotene.

Brüggemann et al. (2) reported that the color formation was not due to antimony trichloride, but to antimony pentachloride usually contained in the commercial sample of antimony trichloride.

In this study, the estimation of vitamin $A$ and of $\beta$-carotene with antimony pentachloride was attempted, and the method was compared with that using antimony trichloride.

\section{EXPERIMENTAL AND RESULTS}

The method for estimating vitamin A with antimony trichloride was carried out according to that described in "Eisei Shikenho" (An Official Methods of Analysis authorized by Pharmaceutical Association of Japan).

1. Estimation of Vitamin A in Cod-Liver Oil by Both Methods

The cod-liver oil was saponified and extracted with ether. After distillation of the ether, the unsaponifiable residue was dissolved in chloroform. $1 \mathrm{ml}$ each of the solution was added to $9 \mathrm{ml}$ of antimony chloride solution. The color formed was estimated colorimetrically at $620 \mathrm{~m} \mu$.

Antimony trichloride solution used contained $250 \mathrm{mg}$ of the chloride per $\mathrm{ml}$, while the antimony pentachloride solution used contained various amounts 
of the pentachloride. To each $100 \mathrm{ml}$ antimony chloride solution, $1.0 \mathrm{ml}$ of acetic anhydride was previously added.

By changing the amount of $\mathrm{SbCl}_{5}$ added, various colorations were observed $; 23.4 \mathrm{mg} / \mathrm{ml}$ gave reddish blue, $2.34 \mathrm{mg} / \mathrm{ml}$ blue just like the color given with $\mathrm{SbCl}_{3}, 1.2 \mathrm{mg} / \mathrm{ml}$ faint but distinctive blue, and $0.15 \mathrm{mg} / \mathrm{ml}$ reduced the color markedly. All the color densities developed by adding $\mathrm{SbCl}_{5}$, however, were smaller than those developed by adding $\mathrm{SbCl}_{3}$ as shown in Table $\mathrm{I}$.

TABLE I

Colorimetric Determination of Vitamin A in Cod-Liver Oil with $\mathrm{SbCl}_{3}$ and $\mathrm{SbCl}_{5}$

\begin{tabular}{|c|c|c|c|c|c|c|c|}
\hline \multicolumn{2}{|c|}{ Reagent added } & \multicolumn{6}{|c|}{ Vitamin A content (I.U./g) } \\
\hline Kind of chloride & Concentration & 1 & 2 & 3 & 4 & 5 & 6 \\
\hline $\begin{array}{l}\text { A. } \mathrm{SbCl}_{3} \\
\text { B. } \mathrm{SbCl}_{5} \\
\qquad / A(\%)\end{array}$ & $\begin{array}{c}m g / m l \\
250 \\
2.34\end{array}$ & $\begin{array}{c}2000 \\
1860 \\
93.1\end{array}$ & $\begin{array}{r}2013 \\
1816 \\
90.2\end{array}$ & $\begin{array}{r}2127 \\
1893 \\
88.9\end{array}$ & $\begin{array}{r}1401 \\
1296 \\
92.5\end{array}$ & $\begin{array}{r}1451 \\
1237 \\
85.3\end{array}$ & $\begin{array}{r}1414 \\
1345 \\
95.1\end{array}$ \\
\hline $\begin{array}{l}\text { A. } \mathrm{SbCl}_{3} \\
\text { B. } \mathrm{SbCl}_{5} \\
\quad B / A(\%)\end{array}$ & $\begin{array}{r}250 \\
1.2\end{array}$ & $\begin{array}{r}1145 \\
1010 \\
88.3\end{array}$ & $\begin{array}{r}1122 \\
987 \\
87.9\end{array}$ & $\begin{array}{r}1148 \\
967 \\
84.1\end{array}$ & & & \\
\hline $\begin{array}{l}\text { A. } \mathrm{SbCl}_{3} \\
\text { B. } \mathrm{SbCl}_{5} \\
\quad B / A(\%)\end{array}$ & $\begin{array}{r}250 \\
0.15\end{array}$ & $\begin{array}{r}3033 \\
129 \\
4.25\end{array}$ & $\begin{array}{r}3153 \\
129 \\
4.09\end{array}$ & $\begin{array}{r}3033 \\
125 \\
4.12\end{array}$ & & & \\
\hline
\end{tabular}

If the commercial sample of $\mathrm{SbCl}_{3}$ contains about $0.06 \%$ of $\mathrm{SbCl}_{5}$ as reported by Brüggeman et al., the reagent containing $0.15 \mathrm{mg}$ of $\mathrm{SbCl}_{5}$ per $\mathrm{ml}$ may be sufficient to form the color. Impurity of the reagent and degradation of the $\mathrm{SbCl}_{5}$ in the procedure might cause lower values.

2. Estimation of Vitamin A with Antimony Pentachloride under a Certain Condition

From the result of the above experiments, it is obvious that the concentration of $\mathrm{SbCl}_{5}$ to be added vitamin $\mathrm{A}$ need not be so high as $\mathrm{SbCl}_{3}$. In

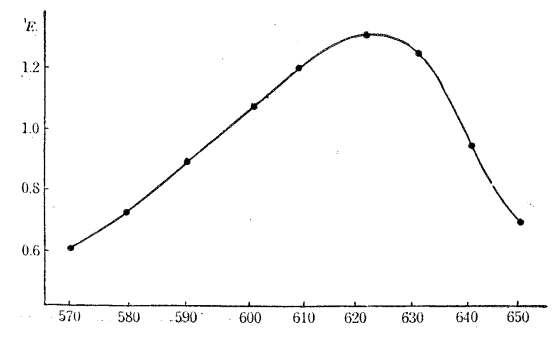

Wavelength $(\mathrm{m} / \mathrm{l})$

FIc. 1 Absorption Spectrum of $\mathrm{SbCl}_{5}$ Vitamin $\Lambda$

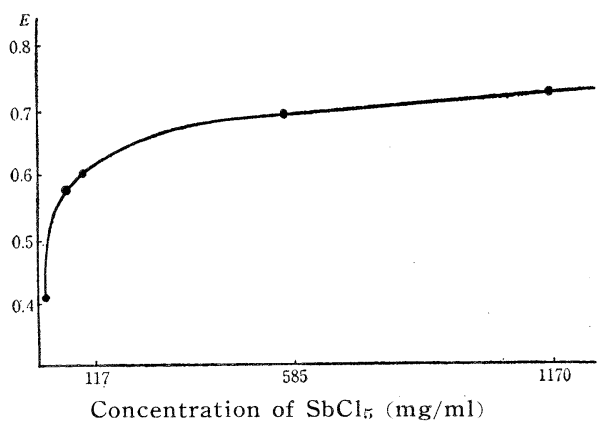

Fig. 2 Effect of Concentration of Reagent on Color Density 
usual method for determining vitamin $\mathrm{A}$ with $\mathrm{SbCl}_{3}, 1 \mathrm{ml}$ of chloroform solution of the unsaponifiable matter was added to $9 \mathrm{ml}$ of $\mathrm{SbCl}_{3}$-reagent. The smaller the volume of the $\mathrm{SbCl}_{3}$-reagent to be added, the more rapid and simpler the procedure might be. Thus $3.5-4.5 \mathrm{ml}$ of chloroform solution of the unsaponifiable matter was added to $0.01 \mathrm{ml}$ of $\mathrm{SbCl}_{5}$-reagent in the present studies.

Estimation of Absorption Maximum-After adding $0.01 \mathrm{ml}$ of $\mathrm{SbCl}_{5}$-reagent to $3.5 \mathrm{ml}$ of the sample, absorbance was estimated spectrophotometrically at each wavelength. The results are shown in Fig. 1. The maximum absorbance lied at about $620 \mathrm{~m} \mu$ in agreement with the case of $\mathrm{SbCl}_{3}$-vitamin A compound.

Effects of Changing Concentrations of $\mathrm{SbCl}_{5}$ on Absorbance-In this experiment, the reagents containing $11.7,58.5,117,585,1170$, and $1560 \mathrm{mg}$ of $\mathrm{SbCl}_{5}$ per $\mathrm{ml}$ respectively were used. Spectrophotometric estimation at 620 $\mathrm{m} \mu$ was carried out 15 seconds after adding the reagent to the sample. The results are shown in Fig. 2. At the concentrations higher than $585 \mathrm{mg}$ per $\mathrm{ml}$ of $\mathrm{SbCl}_{5}$ it was inconvenient to carry out the procedure because of the emission of smoky chlorine gas. Further addition above $1170 \mathrm{mg}$ per $\mathrm{ml}$ resulted in the change of the color. So the concentration of $\mathrm{SbCl}_{5}$ was most conveniently used at $468 \mathrm{mg}$ per $\mathrm{ml}$.

Decoloration of Colored Complex - Standard cod-liver oil (J.P. VI) was used for determining the content of vitamin A. Each absorbance was determined at the interval of $15,20,30,40,50,60,70,80$, and 90 seconds, respectively, after adding $0.01 \mathrm{ml}$ of $\mathrm{SbCl}_{5}$ reagent to $4.5 \mathrm{ml}$ of the sample solutions. The estimation was unable to carry out more rapid than 15 seconds after adding the $\mathrm{SbCl}_{5}$-reagent. The results are shown in Fig. 3.

Standard Curve of Vitamin A Determined with $\mathrm{SbCl}_{5}-$ Cod-liver oil samples containing 2.5, 5.0, 7.5, $10.0 \mathrm{I}$. U. of vitamin A, respectively, were colorimetrically determined under the conditions as described above. The results gave linear relationship as shown in Fig. 4.

Colorimetric Determination of Vitamin A in Cod-live Oil-The cod-liver oil containing 2560 r. u. per $\mathrm{g}$ of vita-

min $A$ as estimated previously with

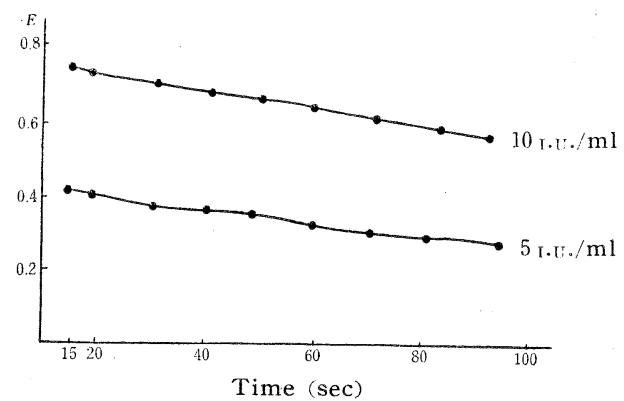

FIG. 3 Rate of Decoloration

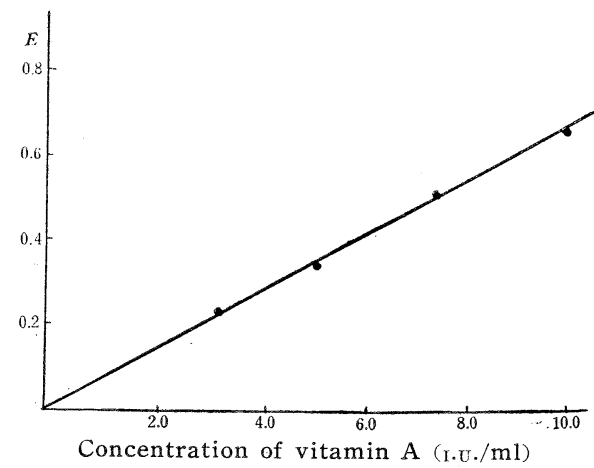

Fig. 4 Standard Curve of Vitamin A Determined with $\mathrm{SbCl}_{5}$ 
TABLE II

Estimation of Vitamin A Content in Cod-Liver Oil

\begin{tabular}{cccc}
\hline No. of experiment & $T$ & $E$ & A content \\
\hline & $\%$ & & I.U./g \\
1 & 32.2 & 0.4908 & 2500 \\
3 & 32.3 & 0.4922 & 2500 \\
4 & 32.3 & 0.4922 & 2500 \\
& 32.2 & 0.4908 & 2500
\end{tabular}

$\mathrm{SbCl}_{3}$, was used as a sample. The value of vitamin $A$ in the oil was on an average $2500 \mathrm{I}$.U. as shown in Table II.

3. Estimation of $\beta$-Carotene with Antimony Pentachloride - Crystalline $\beta$-carotene was used as a sample. To each $3.5 \mathrm{ml}$ of the chloroform solution containing various amounts of $\beta$-carotene, $0.01 \mathrm{ml}$ of the reagent containing $468 \mathrm{mg}$ of $\mathrm{SbCl}_{5}$ per $\mathrm{ml}$

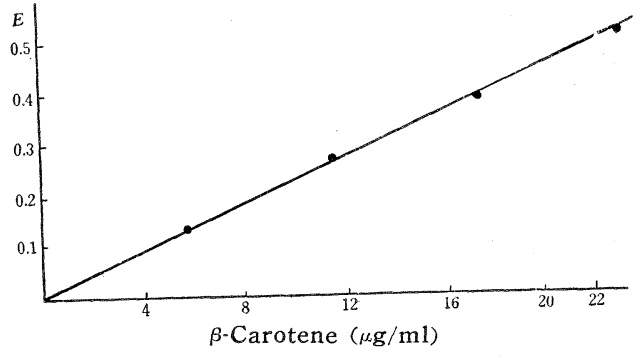

FIG. $5 \quad$ Standard Curve of $\beta$-Carotene Determined with $\mathrm{SbCl}_{5}$ was added, and the color produced was colorimetrically estimated at $620 \mathrm{~m} \mu$. Almost linear standard curve was obtained at the concentrations of $0-22$ $\mu \mathrm{g}$ per ml. (Fig. 5).

\section{DISCUSSION}

Brüggemann et al. reported that the Carr-Price reaction was due to the formation of a colored substance by the reaction of vitamin $\mathrm{A}$ with $\mathrm{SbCl}_{5}$ which is ordinarily contained in the commercial sample of $\mathrm{SbCl}_{3}$, and their view was confirmed by the authors. Namely, the color developed with $\mathrm{SbCl}_{5}$ had the same absorption maximum at $620 \mathrm{~m} \mu$ as that with $\mathrm{SbCl}_{3}$, and both vitamin $\mathrm{A}$ and $\beta$-carotene can be determined colorimetrically using $\mathrm{SbCl}_{5}$. They reported further that the amount of $\mathrm{SbCl}_{5}$ sufficient to develope the color corresponded to 0.06 per cent of that of $\mathrm{SbCl}_{3}$, a finding which could not be confirmed by the authors. The amount of $\mathrm{SbCl}_{5}$ required for coloration was $1 / 3150$ of that of $\mathrm{SbCl}_{3}$. The color formed with $\mathrm{SbCl}_{5}$ faded as rapidly as that with $\mathrm{SbCl}_{3}$. The addition of a very small amount of the reagent made the procedure easier and more rapid, and the further color change was considerably reduced. Another convenience of using $\mathrm{SbCl}_{5}$ was the prevention of staining the glass apparatus by the $\mathrm{SbOCl}$ formed.

$\beta$-Carotene could also be colorimetrically estimated using $\mathrm{SbCl}_{5}$. Comparing the standard curve of $\beta$-carotene with that of vitamin $A$, the mechanism of formation of color in $\beta$-carotene with $\mathrm{SbCl}_{5}$ might be different from that of vitamin A. These experiment suggests that estimation of vitamin A with $\mathrm{SbCl}_{5}$ in the presence of much $\beta$-carotene will give false values. 


\section{SUMMARY}

Vitamin $\mathrm{A}$ and $\beta$-carotene form with $\mathrm{SbCl}_{5}$ color substances having an absorption maximum at $620 \mathrm{~m} \mu$, at which wavelength the colorimetric estimation can be easily and rapidly carried out.

Sufficient color for estimation is obtained by adding $0.01 \mathrm{ml}$ of $\mathrm{SbCl}_{5}$-chloroform solution containing $468 \mathrm{mg}$ of $\mathrm{SbCl}_{5}$ per $\mathrm{ml}$ to $3.5 \mathrm{ml}$ of sample chloroform solution.

Staining the glass by the $\mathrm{SbOCl}$ formed in the procedure was insignificant with the use of $\mathrm{SbCl}_{5}$.

\section{REFERENCES}

1. Meunier, P., Compt. Rend. Acad. Sci. 221, 64 (1945).

Meunier, P., Bull. Soc. Chim. France Mém. (5) 13, (1946).

2. Brüggemann, J., Krous, W., and Tiews, J., Chem. Ber. 85, 315 (1952). 